\title{
Exit Hercules: Ronald Dworkin and the Crisis of the Age of Rights
}

\author{
Lorenzo Zucca \\ King's College, London
}

\begin{abstract}
This paper singles out the late Ronald Dworkin as the legal and politicalphilosopher who best interpreted and represented the rise, success and fall of the age of rights. Three pillars are central to the age of rights: a strong liberal agenda, a powerful judiciary capable of quashing legislation incompatible with rights, and a coherent theory singling out the special moral primacy of rights. Each one of these pillars, which are central to the thought of Dworkin, are now being challenged; this contributes to the explanation of the root causes of the crisis of the age of rights.
\end{abstract}

\section{KEYWORDS}

Rights; conflict of values; liberalism; judicial review; value monism; value pluralism

\section{Introduction}

The age of rights is in crisis. Particularly so, now that Ronald Dworkin has passed away: without him, rights lose their most successful spokesperson that incessantly tried to show their objectivity, independence and deep harmony. It takes great faith and hope in human rationality to believe that we can come up with a single — right — answer based on rights to any ethical, moral and legal dilemmas that are societies face. Ronald Dworkin attempted just that throughout his long career that just came to an end. He is the greatest of all the advocates of rights, and deployed all his vigour, sharpness and rhetorical verve to defend the claim that rights must be taken seriously and if we do so, and understand them appropriately, they point our communities in the best possible direction for the future.

When I speak of the age of right, I refer to an historical period during which rights became the central element in legal, political and moral language; not only that: rights also made, or seemed to make, a positive difference in the way legal, political and moral decisions were taken. Dworkin happened to live the golden age of rights and embraced it wholeheartedly highlighting the strengths and achievements that could be reached in their name. It nonetheless seems to me high time to evalu- 
ate the contribution of rights in a more balanced light: I am not going to suggest that rights do not make any difference, but what I would like to stress that they do not seem to make as much difference as they trumpet. They are but another element in the moral horizon of political societies. Moreover, rights no longer seem to provide compelling arguments to decide cases, perhaps precisely because of their success: their scope has widened beyond imagination, so each of the rights protected by constitutions or international treaties pull in competing -at times conflictingdirections. Rights frame disagreement as much as they frame agreement.

The period I am thinking about spans from 1948 to 1989, from the Universal Declaration of Human Rights to the fall of Berlin's wall. The starting point is obvious: the international community declared universal rights of all human beings at the end of the most devastating global confrontation. The ending point is more controversial, and it will become more apparent later on why I regard it as such. In fact, I should say that it is better described as both the highest point and the beginning of a decline for rights. The decline includes various phenomena amongst which we can cite: the reversal of fortune of a liberal agenda of rights with the return of conservative forces mining the march of rights and at times siding with religious groups to counter liberal reforms in the name of rights. I'd like to suggest that Ronald Dworkin's death is one of the lowest points in the decline of the age of rights.

Dworkin was born in 1931, and was 17 when the UN approved the UDHR. He was coming of age at exactly the right time, or perhaps the rights time. His early maturity was characterized by the American experience of rights protection, and in particular he witnessed the very activist, and liberally minded, Warren court (1953-1969) while it tried to enhance equality and freedom in the US through a judicially enforced bill of rights. The decline, of the age of rights corresponds to the decline of the model of rights' protection as conceived in America. The American model as shaped by the historical events since 1948 has three fundamental dimensions: politics, law and morality. At the political level, what pushed forward the American conception of rights was a liberal credo that America wanted to spread throughout the world. The Supreme Court happened to be the voice of that liberal credo, and the Warren Court in particular was the prime interpreter of it. The liberal credo was at the beginning a unifying credo in the US, especially when compared and contrasted with the Communist credo. At the legal level, we have already hinted at it, the institution that did most of the work in spreading the liberal credo was the Supreme Court: this informs the second tenets of Dworkin's faith in rights, and the conviction that judges are there to up- 
hold them. Finally, at the moral level- rights have become the moral lingua franca in which we cast any claim of injustice within and beyond the state. Its success as a discursive practice is not always matched at the practical level -they do not always redress the injustices they address. Moreover, their success as an argumentative tool shows major weakness at the philosophical level since it is a real problem to explain the universality, force and coherence of rights at the moral level. Dworkin did more than anyone else to show why we'd better believe in the moral truth of rights and why they always point us in the best direction. His task was really Herculean and in many ways he singlehandedly engaged in a gigantic philosophical task: to explain the independence and the unity of the department of value.

Whether Dworkin was successful in that task is beyond my focus here. What matters is that without him, rights lose their hero and are likely to appear in a dimmer light, incapable of withstanding the charges of their critics. I will endeavour to show to what extent the age of right as I define it has benefited from Dworkin's argument and why it is now in trouble, if not at the last stop of that journey. Following the three pillars described above, I will focus on rights as part of a liberal agenda in section 2; I will then explain the role and function of courts in enhancing the protection of rights; and I will then discuss Dworkin's attempt to provide a unitary and independent foundation to the whole domain of value within which rights play a central role.

\section{Liberal Rights}

The age of rights was a response to $\mathrm{WW} 2$, the most brutal war of all times. Human rights were declared as the bedrock of any decent society in the world. To declare them was a first big step; the aim was to provide a common basis for all the nations, a foundation for peaceful mutual relations. But at the very same time, the world was divided into two blocs vying for ultimate power and for two opposite views of power: the western bloc stood for the ideals of liberal democracies and free markets, whereas the eastern bloc represented authoritarian states and a state-run economy. In this climate, each bloc needed to find and fund an ideology through which it could claim moral superiority. The western bloc naturally embraced a liberal agenda based on first generation rights that aimed at protecting the autonomy and dignity of the individual. The eastern bloc resisted the ideology of individual rights and instead focused on the idea of a strong collectivity based on the idea of equality. 
Ronald Dworkin's coming of age coincided with the Universal declaration of human rights (UDHR, 1948). His formative years as a young boy in America were marked by the looming presence of the war. The UDHR ushered in a new chapter in his life, which he embraced wholeheartedly by becoming the greatest advocate of rights at home and abroad, and universally. However, his conception of rights was partisan: he represented better than anyone else a left-wing liberal position, which he incessantly defended for over 50 years. Indeed, one of his longstanding political and philosophical battles was to reconcile mainstream liberal views with left-egalitarian positions. While the success of liberal rights is beyond dispute, their egalitarian dimension is often the source of bitter disagreement. Dworkin's left egalitarian sensitivity must have been accrued by the seminal case of the Supreme Court in Brown $v$ Board, 1954, where school segregation between white and black children was ruled to be unconstitutional. Another seed of his vision was planted: courts could be the agent of the implementation of a left-wing liberal manifesto.

However, the left wing liberal manifesto is based on the tension between liberty and equality. Some even insist that to reconcile liberty and equality is a conceptual impossibility. Isaiah Berlin, one of Dworkin's main philosophical mentors, strenuously defended the idea that sometimes values conflict in a way that cannot be reconciled. Human beings, and human societies, have different goals that cannot be reduced to one single formula. If a society pursues the maximisation of liberty in one of its many guises, it is conceptually impossible to maximise at the same time, and to the same extent, equality. This is the gist of pluralism, which goes hand in hand with a modest conception of liberty, namely negative liberty - that is freedom from interference of the state in one's own private decision about what makes a life worth living. In response to Berlin, Dworkin argued that negative liberty is not the only way of conceiving of liberty. An alternative may be the following: liberty is 'freedom to do whatever you like so long as you respect the moral rights, properly understood, of others. ${ }^{1}$ You can see in this reply a very powerful, albeit largely rhetorical, move that combines Dworkin's conception of liberty and equality with moral rights. For Dworkin, an appropriate understanding of rights is what can help us mediate conflicts between political values. In fact, moral rights mark the boundaries between, and provide the glue for, a harmonious view of all political values. For example, when the state wishes to raise taxes in order to improve on the medical care of more

1 Ronald Dworkin, Justice in Robes, (Belknap Press of Harvard University Press 2006) 112. 
vulnerable people, one may describe this situation as a conflict between liberty and equality. Rich people would stand for their liberty not to be interfered with their property, while poor people would claim for better medical care in the name of equality. According to Dworkin, the state is justified to impose taxes on rich people without infringing liberty, because what they own in excess is not rightfully theirs. Here, the conflict between values is not so much resolved but displaced at the level of moral rights- in this sense Dworkin wants to focus all our disagreement on whether or not we are entitled to some things in the name of rights. For Dworkin, political conflicts in a community are solved by appeal to arguments that feature moral rights very prominently if not exclusively.

Dworkin puts moral rights at the centre of his liberal agenda, just like individual rights are at the centre of the US liberal agenda, and more generally of the agenda of western liberal democracies. Moreover, moral rights are not mere aspirations, but they have a clear and sizeable legal impact by way of constitutional interpretation. Dworkin encapsulates a legal constitutional development that is already clear from Brown $v$ Board, the first major decision of the Supreme Court presided over by Chief Justice Warren (1953-1969). This court is often perceived as one of the most activist as well as the most liberal. The court was very active in three areas in particular: whenever an enumerated right-such as free speech-was a stake, whenever political conflict would prevent social progress, and whenever minorities were clearly discriminated. In each of these three areas, rights are deeply interwoven with the liberal agenda of the court. Rights are both means of the court to advance the agenda, and ends in themselves of that agenda.

One right above all, the right to free speech, comes to be regarded as the core principle of any democracy, the individual right par excellence. For liberals, free speech is the guarantee of a properly working political system where serious and genuine disagreement is played out in public and is supposed to lay bare truths and dispose of wrongs and mistaken ideas. Free speech is particularly useful for liberals when applied to politics and political officials. The Warren Court was central in advancing that thesis in NYv Sullivan, where it was held that a public official could only win a libel suit against the press if he could prove that the statement was made with 'actual malice' and not simply showing that the statement was incorrect. While Dworkin praised the result of the case, which makes it more difficult for the press to be bullied into burying some news for fear of being sued, Dworkin also criticized Brennan's leading opinion that seemed to give priority to an instrumental reading of free speech rather than a constitutive one. The instrumental argument is the one 
that links democracy and free speech and argues that the latter promotes the former, and that is why the right is valuable. Dworkin suggests that free speech should also be conceived as a constitutive right given that it sustains the idea that each one of us has moral agency and is therefore capable of choosing which opinions are worth being followed and which ones are not. To insist on moral agency and responsibility puts the individual at the centre of the picture and the state is distrusted as a benign gatekeeper who decides which opinions can be heard and which ones cannot. By denying the access of some opinions to the general market of ideas, the state would deny the dignity and personhood of human beings who are not regarded as being capable to elect autonomously what to believe in. Dworkin suggested that Brennan's original instrumental reading could be expanded to include the constitutive reading of free speech- in other words the right of free speech ought to be regarded as both a means and an end. The discussion on free speech also shows that disagreement is possible within the liberal camp, even if the goal is common.

Another fundamental tenet of the liberal camp is the fight for sexual and reproductive deregulation. This is a field within which, there was little hope for progress from within politics, and probably explains why the court felt so keen to intervene and give a new surprising grounding to the whole debate: the right to privacy emerged as one of the core unenumerated rights from the jurisprudence of the court. In Griswold $v$ Connecticut, the Supreme Court planted the seeds for many other great liberal decisions in the fields of sex and reproduction. The case itself made it unconstitutional to prohibit contraception between married couples. But the great legacy of the case is to announce a core un-enumerated right which will be at the centre of very many other decisions, including Roe $v$ Wade (1973). Liberals in the Court thought that the right to privacy - understood as the right to make one's own decisions about sex and reproduction unencumbered by the judgment of the state-was central to the Constitutional enterprise, even if it were not explicitly mentioned in the list of enumerated rights in the text. Conservatives since then heavily criticised the liberal activism of the court, in particular when it essentially made up from scratch rights that were not even remotely mentioned. Dworkin makes a case against conservatives suggesting that the very distinction between enumerated and un-enumerated rights is bogus. For Dworkin, the Constitution is couched in very sweeping moral language that is there to be interpreted; clauses referring to the equal protection of the laws, or to due process call for a great deal of further instantiation, and judges are there to bring the constitutional enterprise forward and cast the best possible light on the text. It nevertheless remains clear 
that if some rights are explicitly mentioned and others are not, then this must be evidence of the constitutional choices of the framers that are not fully catered for in Dworkin's viewpoint. It seems unavoidable to suggest that Dworkin, as an advocate of liberal rights, had a great stake in protecting the status of the right to privacy.

Indeed, as mentioned above, the right to privacy is again at the core of the most important judicial victory for the liberal camp, that is Roe $v$ Wade - which established the right to abortion on the basis of the right to privacy. A woman should be allowed to make up her own mind about as private a matter as pregnancy, and the state is not justified in preventing women from choosing not to abort their pregnancy. If Roe $v$ Wade was the victory of a great battle for liberals, it did not amount to the winning of the war on sexual reproduction and liberation. Conservative forces took Roe $v$ Wade as the principal example of what can go wrong when the court advances too aggressively a political agenda. The decision backfired and the last 40 years were spent to undo the decision that is heralded by Ronald Dworkin as one of the greatest. This is certainly true from a liberal viewpoint, but it also entailed a very deep political polarisation between liberal and conservatives, between right and left wing. It also raises the question of how far can a court go when attempting to protect a right that is very controversial from both a constitutional and political viewpoint. The right to privacy contributed to further victories for liberals, in particular the overruling of Bowers, which gave constitutional approval to laws criminalizing homosexual sex in private. In Lawrence $v$ Texas, the Supreme Court led by the most Dworkinian of justices, Justice Kennedy, found the Texas statute criminalizing homosexuality unconstitutional on the basis of the right to privacy. At first sight, one may claim that free speech and privacy are co-extensive, and can be reduced to, negative liberty- but Dworkin explains why this is not the case: a political community is genuinely liberal if it treats its individuals as fully fledged moral members. To do so, individuals have to take part to the political process, they have to have a stake in the political process, and they have to be independent from the political process even if they are subject to its decisions. The first two conditions are easy to grasp. An individual that cannot voice her concern in the political process is not a member of the community. And also an individual who does not see his interest represented in the political process, can hardly accept the final decision of the community since his viewpoint has never been accounted for.

The third condition is more difficult to grasp, since it is hard to understand how one can possibly be independent and bound at the same time. Or to put it differently, how is it possible that individual freedom 
can be furthered by collective self-government? Dworkin suggests that an individual endowed with self-respect and dignity understands that a political community is a common endeavour where responsibility for decision on important policies is given to an ultimate authority. He compares that situation with a musical orchestra, where individual musician endowed with self-respect understand that for the orchestra to work they have to rely on the choices of the musical director. It is not the case that their independence is curtailed or limited; in such a situation, their independence is compatible with the idea of being directed. Dworkin suggests that in political matters, it is even more so the case. People can accept that moral independence exercised on question of private life is compatible with having issues of justice decided by a collective body when individual interest compete and collide and the community requires a common standard for all that compromises between divergent interests. Of course, in Dworkin's view, competition and clash of interests can always be interpreted in a way that dispel a fundamental conflict of values and the compromise to which Dworkin aspires is always couched in terms of rights.

We have already seen, however, how divisive some liberal positions could be, in particular in relation to sexual and reproductive freedom. The gap that was being excavated between liberal and conservative was to widen progressively in the 70 's and in the 80 's. What seemed to keep the country together was in those years the fact that the US had a foreign common enemy, who was particularly inimical to the idea of individual rights from the liberal viewpoint. The fall of the Berlin wall in 1989 gave rise to the all-encompassing crisis of liberal values in the west. Liberal western democracies based on individual rights had won the cold war, but they were likely to become victim of their own success. Once its competing ideology was gone, the liberal dogma was much more likely to show all its weaknesses and internal contradictions.

The fall of the Berlin wall, made Isiaha Berlin's idea of value pluralism even more popular and widespread. But value pluralism was the biggest threat for a harmonious liberal recipe based on moral rights. Not that Berlin's ideas are illiberal. To the contrary, he is a very committed liberal and believes that value pluralism - the idea that values are objective and incommensurable - is the heart of liberalism. For Berlin, liberalism should promote diversity as far as possible. Every individual should be protected in the free pursuit of what he thinks best for the purpose of his self-development and flourishing. The society should refrain as far as possible from imposing any overarching set of norms that would stifle diversity and promote one homogeneous and harmonious position as to 
what is a good life. Value pluralism has a great explanatory power, and highlights the appeal of liberalism as committed to diversity, but it is also underlies a major challenge for liberalism in so far that it recognizes that some moral disagreement is the stuff of tragic conflict and there is no way in which all values can be made to cohere in a harmonious whole. The challenge is to be able to accept tragic conflicts, while devising a method to cope with them without polarising the society.

In the post-Berlin's wall world, human rights spread their wings in liberal democracies. The rights revolution swept the whole world and in two decades most countries adopted constitutionally entrenched rights with judicial review. These included all eastern European Countries, as well as most commonwealth countries including the UK itself. However, the spread of human rights documents and the introduction of judicial review has not always been an unequivocal success. In some countries, human rights are used as an instrument to fuel social and political conflicts. Societies are being divided along moral, political and religious lines and human rights advocates are not capable of mediating these conflicts in a way that does not leave moral or political residue.

Polarisation became even starker with $9 / 11$, which brought a new form of global division along national identity lines, based in particular on religious difference. Religious Identity is a strong form of belonging coupled with a strong set of beliefs that can be hard to square with other equally strong beliefs. Rights in this environment are not always suited to help mediate between the concerns of liberal polities and those of religious communities. On sexual morality and reproduction, for example, old divisions resurface and liberalism's commitment to diversity can hardly be squared with its commitment to sexual freedom. Value pluralism asks us to understand and accept other worldviews, the problem arises when other worldviews want to impose themselves on the rest of the society on the ground that they are the only ones to hold the truth about moral matters.

Dworkin himself had to acknowledge that liberal democracies, starting with the US, had received a massive blow in the last 10 years or so and came to ask whether Democracy is possible in this circumstances of deep moral and political division. The return of religion fuelled deep seated divisions and promoted confrontation rather than compromise. Despite his bleaker look at present day liberal societies, Dworkin insisted that societies need a common ground, one big idea that can be shared and from which disagreement can be started and articulated. The big idea he has in mind is that of dignity and it has two major implications. Firstly, dignity means to recognize the special and intrinsic value of everyone's 
life. Secondly, everyone has personal responsibility to make decisions concerning how to live the best possible life. Unfortunately, this optimistic minimal common ground seems to ride roughshod over the fact that sometimes some worldviews are simply incompatible with others. It is not necessarily a holistic incompatibility all the way through, but it surfaces on important decisions that need to be taken collectively-such as the nature of marriage, the permissibility of euthanasia and other moral dilemmas that cannot find an answer that will appease everyone. Dworkin's hope to find a common ground defies the widespread belief that, perhaps, the only thing there is in common is the fact of unbridgeable pluralism.

\section{Courts}

Moral rights need their advocates and, more importantly, they need institutions who are likely to implement them and argue for them. Post-war America found in the Warren Court a formidable bastion in defence of a liberal view of rights. The US Supreme Court judicial activism is the second important pillar of what I call the age of rights. Not only rights were declared in bills of rights, but they were also effectively protected by the intervention of courts. At the same time, post-war Europe, in particular Italy and Germany were cutting their teeth with a brand new set of constitutional instruments inspired by the American experience and completed with strong power for their respective constitutional courts. Constitutional courts that are composed by elites of a country tend to be progressive and liberal, and so they naturally advance a mainstream liberal agenda on free speech, decisional privacy, sexual freedom and procreation.

Needless to say, courts became for Dworkin the place where it all happens. A liberal agenda can be carried forward in the name of rights, since rights are trumps against policies that are shaped by the aggregation of interests. Rights are not purely instrumental, they are constitutive and they resist most forms of consequentialist (or instrumentalist) thinking. Courts have the power to argue in favour of rights and against legislation that does not take rights seriously. Judges can engage in detailed arguments of principle and can apply them to the facts of the case to help carry forward the constitutional ethos. Courts, however, are not fully trained in moral arguments and Dworkin's liberal agenda aims at convincing judges that they should reason with principles that are embedded in rights.

But first, Dworkin had to overcome an important hurdle: HLA Hart's influential book, The Concept of Law, offers an understanding of 
law that does not a much place for morally oriented principles. The building block of law is the notion of rules; legal rules do not invite judges to engage in moral reasoning. They invite them to interpret legal materials carefully and to apply rules to the facts by religiously respecting the words crafted by the legislator. Hart's Positivism does not rule out altogether the possibility for judges to engage in moral reasoning: sometimes rules are crafted in a way that explicitly requires them to draw some moral lines; so for instance the unfair contract terms legislation requires judges to establish the meaning of unfairness. However, the link between law and morality is purely contingent and does not arise if rules are crafted in a technical and precise way. As we all know very well, Dworkin attacks precisely on that point and suggests that the law is not made only of precise rules, the dimension of which is one of validity. The law is made of principles that are an integral part of any legal practice; principles are different in kind from rules to the extent that they behave differently since they do not prescribe a precise set of actions. By arguing that principles are a constitutive part of the law, Dworkin also suggests that there is a necessary link between law and morality and that judges have an obligation to bring morality to bear whenever the law is unclear or incomplete. In particular judges have to determine the moral rights and obligations of all parties to litigation in a way that reflect sophisticated moral arguments. Morality requires judges to take rights seriously.

There is another reason for Dworkin to provide a competing theory of law to Hart's. A positivist sometimes has a hard time defending his liberal views and arguing that the law can well be contrary to his own liberal convictions and still be fully valid. Dworkin probably found Hart's position unsatisfactory when faced with Lord Devlin's arguments on prohibiting homosexuality on grounds of immorality. Hart, as a positivist, was not entitled to say that the law could not interfere with individuals' private choices as a matter of principle. Dworkin thought that this was a basic weakness of the positivist position that could not properly advance a liberal agenda even if it wanted to. Dworkin's alternative answer to the debate on homosexuality is to argue that as a matter of principle, and basic rights, no individual can be coerced to behave against one's own private or sexual preferences. No law could be considered as binding if it infringed those basic rights.

Dworkin's move allows him to have a direct weapon against conservative moralist like Devlin. If legislation is not compatible with moral rights, then it cannot be regarded as valid law. Devlin on the other hand is simply expounding a conventional understanding of the law based on the orthodox doctrine of parliamentary supremacy. Parliament can do 
whatever it wishes, and in moral matters it is perfectly allowed to follow common sense. A positivist has to allow for the fact that law may be bigoted and conservative. Dworkin is unsatisfied with that position and his theory of law incorporates as much as possible his moral position. What Dworkin did not realize though is that to subordinate the law to moral substantive views is a double edged sword: sometimes it may go in a favourable direction, but others it may just go against one's moral preferences. Positivists in that case can distance themselves from the law and criticise from an external viewpoint. A moralist like Dworkin can only resort to internal criticism of the law.

The role of the court, for Dworkin, is to bring moral rights to bear on the interpretation of law. In some cases, like Riggs $v$ Palmer, it is particularly easy to see the appeal of that position. Someone who kills a member of the family in order to inherit his property as stipulated in the will is deemed to forebear his moral right to inheritance because of his wrongdoing. Legislation could not foresee this wicked case, and was therefore silent about it. The judge was faced with a gap, the positivist says. And in the case of a gap, the judge is empowered to use his discretion; the wider the gap, the wider the discretion of course, but in these cases it helps to guide discretion according to common sense morality. In this case, nobody disputes what is the morally right answer; it's a dead easy case. But Dworkin builds on this case the idea that law has no gaps, and no discretion. The judge has a general duty to decide cases on the basis of the best moral interpretation, whenever the law does not provide a clear answer. Moral rights fill every gap of the law, because moral rights underpin the whole legal enterprise.

So the job of the courts is not only to mechanically interpret rules, but it is also if not chiefly about balancing moral principles underlying the law. Principles- we are told- have a dimension of weight rather than validity. They do not apply in a all-or-nothing fashion, but require instead that each policy be evaluated in light of competing moral principles that lie beneath it. If the policy produced displays appropriate concern for all underlying principles, then legislation is sound. Otherwise it will have to be invalidated in the name of its incompatibility with an important moral concern that has been largely overlooked. It is not clear whether this is the 'real' way courts proceed, but Dworkin tried to persuade us that that was the case for the whole of his career. His passionate defence of the court reached a pinnacle when he described them as a forum of principle, a place where moral deliberation can take place in a controlled and judicious way. 
Dworkin's American audience was bound to be more sympathetic to Dworkin's claim than a British audience. The reason was simple, America already displayed a great degree of moral deliberation on the basis of the rights contained in the bill of rights. But Britain lacked a formal, modern, Bill of Rights on the basis of which all law could be scrutinized. And for a long time, Britain resisted the temptation to bring into the law such a mammoth bill that would alter the relation between parliament and the courts. Britain was very happy that other, less liberal, countries adopt a written constitution with judicial review; but a standard British understanding of the law was that it naturally tended toward fairness without having judges to step in to redress the balance.

Having noticed the erosion of that fairness in the 80 's, during Thatcher's government-when the west was battling for its economic deep concerns, Dworkin came to realise, as many other people did, that Britain had vanquished its true liberal commitments that it had inherited from its constitutional history and his great liberal philosophers such as Locke and Mill. He decided to plea for a Bill of Rights for Britain. ${ }^{2}$ Soon thereafter, in the nineties, a new left-wing liberal movement led by Tony Blair campaigned in favour of bringing rights home. Home here means the place where they originally belong, but it also means away from the Strasbourg's court, which was increasingly intervening in British affairs to redress some basic infringements. So in 1998, the HRA comes into force and is the centrepiece of the New Labour constitutional reform that attempts to bring Britain in line with other Western Democracies. Of course, the point of the HRA is not so much to have a substantive impact, but to alter the separation of powers between parliament and the courts and to this effect, the supreme court of the UK is also created independently from the House of Lords where the previous highest judicial formation was sitting.

It is not clear why courts are trusted with a special constitutional power that would bring back rights into one's country legal culture. This idea travelled the world and spread nearly everywhere, but there is no empirical evidence that judicial review based on rights has the effect of restoring, or ushering in, a new age of rights. In the words of one of Dworkin's mentors, Justice Learned Hand: "I often wonder whether we not rest our hopes too much upon constitutions, upon laws, and upon courts. These are false hopes; believe me these are false hopes. Liberty lies in the hearts of men and women; when it dies there, no constitution, no law, no court can save it; no constitution, no law, no court can even do

${ }^{2}$ Ronald Dworking, A Bill of Rights for Britain: Why British Liberty Needs Protection (Chatto \& Windus 1990). 
much to help it. While it lies there it needs no constitution, no law, no court to save it." It is not clear whether the HRA 1998 can restore the spirit of liberty that was seemingly lost under the Thatcher's era. It does not seem to be the case if we judge from the massive backlash against the bill in the British media, not to mention its crusade against Strasbourg.

And perhaps, there is a small grain of truth in the muddled waters of British media. The golden age of liberty in the UK was not secured by courts, but by parliament. So why would it be sensible to hand to a bevy of judges issued from the very same social background the keys of the interpretation of rights? Recent studies show that the rationale for shifting power from parliament to courts through the incorporation of a bill of rights is not so much a concern for universal justice, but a preservation of the control of the society by a bien-pensant elite that is losing its grip through the representative mechanism. Ran Hirschl shows this mechanism very well in the case of Israel for example; the bill of right empowers a bevy of judges from a secular Ashkenazi elite to prevent the loss of control of the Knesset. ${ }^{4}$ The problem is that judicial institutions themselves have to open up and become more representative. The slippery slope is only slowed down, but the grip on a liberal understanding of society is a concrete possibility.

Dworkin had to struggle himself with the curse of judicial power when it eventually became dominated by conservative minded judges appointed by President Bush. ${ }^{5}$ Dworkin was horrified by the prospect of a reversal of liberal fortune and in the last ten years, he began to attack the Supreme Court and in particular its republican judges. Abortion, Euthanasia, gay marriage and many other liberal crusades are all in the hands of a bevy of conservative judges who are not going to abide by a liberal agenda anymore. Perhaps the greatest blow was given during the Bush v Gore litigation, when the Supreme Court had to step in to virtually determine the outcome of the presidential election-obviously in favour of the Republican candidate. Having chanted the greatness of the Supreme court as a forum of principle, it became difficult for Dworkin to start firing bullets against it, while preserving its image and legitimacy. Either the court is a forum of principle, or it is the locus of politics by a

3 Irving Dilliard (ed.), The Spirit of Liberty: Papers and Addresses of Learned Hand(Hamish Hamilton 1954) 189-190.

${ }^{4}$ Ran Hirschl, Towards Juristocracy: The Origins and Consequences of the New Constitutionalism(Harvard University Press 2004) 21-24.

5 Ronald Dworkin, 'The Supreme Court Phalanx'(August 30, 2007) The New York Review of Books <http://www.nybooks.com/articles/archives/2007/sep/27/thesupreme-court-phalanx/?pagination=false $>$ accessed 24 April 2013. 
random bunch of unelected people who may happen to have liberal views but may just as well happen to be very conservative.

Rights in the hand of left liberal judges will advance a left liberal agenda. However, in the hands of conservative judges they will only entrench privileges and inequalities. The problem of principles is that they can always go one way or another. Dworkin would no doubt welcome disagreement, but would be deeply upset about outcomes that are not in line with his political views. How upset can one be before starting to think that the constitutional pact is not for everyone anymore? Is it enough to claim that constitutional rights provide a common ground for everyone, when the constitution allows for major inequalities and discrimination? Can there be a common foundation that is truly common?

\section{Moral Lingua Franca}

From 1948 to today, rights became the lingua franca of any talk of justice at the national and international level. The number of declarations, charters, bills of rights enacted in the last 65 years is astounding. Some experiments have had great success while others are of limited impact, but what is clear is that at an abstract level everyone agrees that the language of rights is the most popular way of casting claims against actual or perceived wrongs. To this extent at least, we live in the age of rights. But there is a discrepancy between the language of rights and the practice of rights both at the national and at the international level. At the national level, the language of rights fuels disagreement rather than contribute to the understanding of society as a common venture. It is not hard to understand this: if every individual can attempt to fit his claims in the language of rights, then any denial would be perceived as a major set back. Setbacks, however, are inevitable as individual interests cast in the language of rights will inescapably conflict one against another. At the international level, the language of rights is even more controversial as any firm understanding of what human rights could require is inescapably tainted with accusation of imperialism and lack of cultural sensi-

tivity. Few wrongs command universal agreement in principle-say for instance torture-but even then they are violated at times despite all prohibitions.

The language of rights may be omnipresent, but it suffers from conceptual imprecision since it applies to many different objects. Dworkin, for example, addresses many different types of rights: legal, political, moral rights of which human rights are but one species. Moreover, there does not seem to be a common structure to rights, even if they all have 
the same point or purpose for Dworkin: legal, political and moral rights are all grounded on the ethical notion of dignity. In Dworkin's theory, political rights are trumps against collective national goals. However, Human rights are not simply trumps against national sovereignty. That would yield a far too thin conception of human rights for Dworkin. Human rights require a precise attitude on the part of everyone, and in particular on the part of the state: people must be treated as deserving full respect in the name of their human dignity. Legal right is the narrowest term and it applies to those rights recognised by the state in legislation or constitutions to which we attach a number of institutional consequences such as the possibility for a court to strike down other norms. So as you can see, the structure of rights varies greatly, but their foundation is the same: dignity as entailing ethical independence and moral responsibility.

Dworkin put his great rhetorical vigour in defence of an understanding of rights that has a common philosophical foundation. His inner citadel- the ultimate idea for which he stands-is that the department of value through which we judge all human actions and achievements has a deep unshakable unity and is completely independent from other fields of knowledge; it has its own internal standards of truth. Dworkin's position argues against two major ideas about values: firstly, he argues that values do not depend on any other deeper thought or action. Secondly, he is squarely opposed to the idea that values are fundamentally incommensurable and at times conflict in an inescapable way. The best understanding of rights can recompose them in a wholly harmonious way without leaving moral residue. The impression though is that conflicts are always resolved in the direction of a left liberal agenda, Dworkin's agenda. How is it possible to convince someone who's not a left-liberal that her rights have been respected and her moral viewpoint has been taken into account properly? Dworkin is firmly aware of the fact that we all disagree about issues of principles, but he's still confident that there is one best moral argument that is capable to display the deep unity of the department of value.

I find it hard to believe that the department of value is unitary, and harmonious in the way Dworkin sees it. This is the case for both morality and law. It is hard to believe that for each hard question there is one clear and final answer as to which values take priority over another. More importantly it is hard to believe that someone will be convinced to accept the idea that if we disagree it is just because I know the objective truth about moral values and you do not. Dworkin eventually accepts this basic intuition and acknowledges in Justice for Hedgehogs that 'the best answer on some occasion is that nothing is any better to do than any- 
thing else. ${ }^{96}$ We reach the paradoxical core of Dworkin's position according to which on occasion the right answer is that there is no right answer. The moral truth Dworkin accidentally stumbles across is that on occasion values conflict and it is not possible to discern one clear ranking between the two. Dworkin muddles the water by suggesting that his opponents escape the question by appealing to answers that are external to the department of value. His opponents would claim for example that the question of truth in morals is not to be investigated from within the department of value, but requires a higher-detached -meta-ethical view that would help to explain and track truth in a way that is independent from substantive questions of value. But this clearly misses the point since value pluralists can say that value conflict as a matter of truth about values without having to search for higher metaphysical or meta-ethical truths. So how would Dworkin arbitrate between the objective truth pluralist hold and that of monists? One of them is right, and the other wrong- but is there an internal answer to morality that tells us who wins? The answer must surely be found at a higher level

The department of value covers all the fields of practical philosophy and goes from Ethics, through Morality to Politics. According to Dworkin there is deep unity across the department of value. The department of value is to be distinguished from the department of science, where the conception of truth functions in a completely different way from truth in the field of value. The truth of moral judgments comes from within- when we are searching moral truth we are trying to figure out what we really believe in. Seeking for truth in the department of science is a different endeavour in so far that it attempts to understand and describe pre-existing natural order that is external to, and independent from, human behaviour. In the department of value, Dworkin holds, dignity is the all encompassing foundation, and common ground, that provides the basis to understand ethical questions about goodness of life as well as moral obligations between people, to end up with the duties that the state has towards individuals.

When applied to law, Dworkin's position is appealing for judges, but puzzling when it comes to the explanation of conflicts of rights. In some cases, rights pull in two opposite direction: freedom of religion allows individuals and groups to organize their lives on the basis of their beliefs. But what if their belief requires them to treat some people better than other simply because they happen to share the same beliefs? Is it possible to discriminate between people on the basis of one's freedom of religion?

${ }^{6}$ Ronald Dworkin, Justice For Hedgehogs (Belknap Press of Harvard University Press 2011) 24 . 
The requirements of liberty and equality are not so easily recomposed in this case. It is possible to suggest intricate alternatives as to how to cope with this situation, but in one way or another something of value must be sacrificed. If it is decided that freedom of religion allows for the discrimination of people, then equality can end up being undermined. If it is decided on the other hand that no belief can justify preferential treatment in the running of a community, then freedom to live according to one's beliefs can also be undermined. I don't believe there is one answer that leaves no moral residue that is one answer that satisfies all the parties and shows a harmonious coherent realm of value. Sometimes it is necessary to choose between two equally important values, and the identity of the society will be shaped precisely by the kind of choices we make. The society as a whole has responsibility to choose between clashing values, and some values will be given preference over others.

Who's the ultimate authority when it comes to decide clashes between conflicting rights? And more importantly even, on what basis can any ultimate authority decide conflicts in a way that preserve the harmony of the department of value. Dworkin believes in a unitary foundation, a common ground that we all share. We have already explored his idea of dignity with its emphasis on ethical independence and moral responsibility. Dworkin believes that rights have the same core and are the fundamental element of any polity that is committed to a proper understanding of value. Judges have a special role in that they have to hold other institutions to their overarching ethical commitment. Rights are those trumps that prevent institutions from taking decisions that go against the foundation of dignity, which is the bedrock of any liberal democratic country.

Dworkin came back to the same point over and over again. If appropriately interpreted, liberty and equality do not conflict but are clearly compatible. This runs against the wisdom of value pluralist according to whom values at times are inescapably in conflict. The bottom line for Dworkin is the notion of hope, a deeply religious notion. ${ }^{7}$ Given that we can choose between interpreting values in a way that conflict or cohere, then he hopes that we will do everything to show that values are always compatible. ${ }^{8}$ The hope that no tragedy would ever occur in our societies

\footnotetext{
7 See Ronald Dworking, 'Do liberal values conflict?' in Mark Lilla, Ronald Dworkin, Robert Silvers (eds), The legacy of Isaiah Berlin (New York Review Books 2001) 90 «Perhaps, after all, the most attractive conceptions of the leading liberal values do hang together in the right way. We haven't yet been given reason to abandon that hope.»

${ }^{8}$ Ronald Dworkin, Justice in Robes (See supra (n. 1)) 116.
} 
flies in the face of the fact that tragedy occurs and that we need a vocabulary to account for those tragedies that involve dramatic conflict of interests. Greek tragedy provides majestic examples: think of Antigone's obligation to bury the corpse of her brother pitting her against the will of the ruler of the city, Creon, who has decreed that those who fought against the city forfeit their right of burial.

One major challenge for rights at the international level is to escape the charge of imperialism and steer away from the deflating perils of relativism. Human rights are either the by-product of western ideology or they collapse into meaningless cultural difference. Either way, human rights are defeated. Dworkin is a relentless advocate of a common foundation of all types of rights including human rights. This foundation is anything but relativistic: we'd better believe in dignity and what it means for each one of us. This is not to say that different legal and political systems will make different choices about what rights to entrench in their constitutions; this is very much a matter of their constitutional history and independence. But in any case, those choices always bring us back to the basic fact that all political rights have the same ultimate foundation. Moreover, that foundation has nothing western or imperialistic. If we think long and hard enough, dignity understood as ethical independence and moral responsibility is truly something that we could all embrace as a foundation of our department of values. The problem with this argument at the international level is that it smacks as deeply western and perhaps even simply left-liberal. Here we have an individualistic conception of human nature that puts all the stress on the individual ability to author his own life and to make decisions that steer his boat in the direction that the individual wishes for himself. Most cultures do not have such a strong commitment with individualism.

There remains a much deeper philosophical problem: some people, even and perhaps especially in the west, do not believe that the department of value has a special independence as Dworkin would like us to believe. In addition to that most philosophers believe that even if values have an objective dimension, it does not mean that they exist independently from our thoughts or actions. Dworkin develops his posthumous argument in an interesting direction, somehow what I had always suspected. Dworkin acknowledges a deep religious attitude even if he does not believe in god. ${ }^{9}$ To have a religious attitude means to reject all forms

\footnotetext{
${ }^{9}$ Ronald Dworkin, Religion without God (forthcoming Harvard University Press).
} 
of naturalism, ${ }^{10}$ which according to Dworkin either equates with nihilism (values are only illusory) or with the idea that values exist but don't have independent existence since they are based on people's thoughts or reactions. Dworkin is a profound religious atheist in that he believes in the objectivity of values and in their complete independence. The department of value is completely self-standing and values have no other foundation but themselves. Dworkin stretches this metaphor to the idea that we have faith in the existence of the department of value. If you cannot see that, you simply lack that faith.

Human rights, however, do not depend on the existence of god. This is also very clear for Dworkin. He's not simply articulating a classic thesis of the religious foundations of human rights. It is not an issue of having rights simply because we have been created in the image of a god that is source of all good and evil. In order to know whether god is good, we need an independent premise to our reasoning. Here Dworkin's argument is distinctively Humean. Dworkin would like to show that religion itself has two distinctive tasks that can be presented as distinctive department of knowledge. One is the science part of religion that tells us several things about the origin and existence of the world and the way in which god has shaped it. The other part of religion is the department of value and concerns the way in which human should behave. Dworkin argues that even for religious people, there is no connection of cause and effect between the department of science and that of value. We are entitled to believe or not to believe in the existence of god and in his omnipotence; however, god's omnipotence in the natural world does not warrant his inherent goodness or evil. In order to know that, we need an independent premise that is internal to the department of value and therefore independent from the faith in the existence of god. People who display a religious attitude have independent faith in the existence of objective, independent values and this does not require faith in the existence of god. So both theistic religious people and atheistic religious people share more than we think when it comes to values. In effect they both share a faith in values (in their objectivity and independence), according to Dworkin.

Dworkin's religious attitude of hope and faith is what is making the hard work in the construction of the domain of value. Faith is what explains the independence of the department of value and hope explains its inner harmony. We can also suggest that, for Dworkin, rights are based on the same premises. To believe in the foundation of human rights is to

10 Ronald Dworkin, 'Religion Without God'(April 4, 2013) The New York Review of Books < <http://www.nybooks.com/article/archives/2013/apr/04/religion-without$\operatorname{god} /$ ?pagination $=$ false $>$ accessed 24 April 2013 
suggest that we have faith in a universal commitment to treat human beings in a certain way-i.e. with full respect that flows from a proper understanding of human dignity. Moreover, to believe that rights can always be composed in a harmonious whole relies on the hope that we can always prevent tragedies and promote happy endings.

\section{Conclusion}

The age of right as I defined it owes much to Ronald Dworkin who embraced it and interpreted in the best possible light he could. Rights became the quintessential tool to bring forward a left wing liberal reform of the society. Through rights implemented by national supreme courts, many liberal battles have been won in matters of individual independence, sexual and reproductive morality and equality between different people. To win battles, however, does not mean to promote a society that is cohesive and harmonious; on the contrary, American society, and the west in general grew more and more divided especially in the last twenty years. Rights can advance agendas but they cannot achieve moral and political unity. Dworkin, like a greek tragic hero, is rolling the rock of rights up against the mountain of disagreement and polarization.

Dworkin's work is monumental in scope and ambition. A modern hero of liberal democracies, he never gave up the fight for justice in the name of rights. Dworkin never gave up hope and faith that a better society could be fashioned in the image of the objective realm of moral values he believes in. Part of his optimism was due to the historical period within which he grew up. The American model of judicial review of rights had made important advancements towards a more liberal and more equal polity at home, and inspired many other liberal democracies to move on with their own liberal agenda.

But any hero has his own Achilles' heel. Dworkin's is the overinflated confidence in what rights can achieve. Rigths are a moral element of a much wider universe. Also rights can have a varying gravitational pullsand they can hardly all go in one direction-harmoniously and without clashing one with another. This basic point requires an argument that cannot be made from within the department of value, as Dworkin would like us to believe. Either value pluralists are right or Dworkin is right; but what would help deciding this disagreement? Would we need a court of principle to establish the winner?

Exit Hercules: with Dworkin passes away the most articulate, energetic, passionate advocate of rights in the XX century. The beauty of his speech and the force of his convictions will inspire many people, and will most probably remain unequalled. It is in this spirit that I argued that 
the golden age of right through which Dworkin lived and which he interpreted so well is now coming to a close. Exit Hercules from the stage. Just like in a Greek tragedy, the light goes off and it all just look like a dream. A very noble dream. 